\title{
Hydrological Model to Simulate Daily Flow in a Basin with the Help of a GIS
}

\author{
Vitali Diaz Mercado', Khalidou M. Bâ ${ }^{2}$ Emmanuelle Quentin³ , Febe Helia Ortiz Madrid², \\ Lilly Gama ${ }^{4}$ \\ ${ }^{1}$ UNESCO-IHE Institute for Water Education, Delft, Netherlands \\ ${ }^{2}$ Centro Interamericano de Recursos del Agua, Universidad Autónoma del Estado de México, Toluca, México \\ ${ }^{3}$ Instituto Nacional de Investigación en Salud Pública, Quito, Ecuador \\ ${ }^{4}$ División Académica de Ciencias Biológicas, Universidad Juárez Autónoma de Tabasco, México \\ Email: vitalidime@gmail.com
}

Received 30 March 2015; accepted 4 July 2015; published 7 July 2015

Copyright (C) 2015 by authors and Scientific Research Publishing Inc.

This work is licensed under the Creative Commons Attribution International License (CC BY).

http://creativecommons.org/licenses/by/4.0/

\begin{abstract}
Hydrological modeling is an essential tool to evaluate water resources in hydrological basins. The time invested in it depends on the structure of the hydrological model chosen, the amount and quality of information required and the efforts invested in calibration. CEQUEAU is a distributed hydrological model developed at the INRS-ETE, Quebec, Canada. The basin is divided into cells and the rainfall-runoff process is simulated cell by cell until the outlet. Recent advances in geomatics make it possible to develop modules integrated in geographic information systems (GIS) to facilitate the processing of information required by hydrological models. The objective of the present investigation is to implement the CEQUEAU model in Idrisi GIS for the hydrological modeling of basins, thereby reducing information processing time and improving limitations in the original version, such as the number of discretization cells and methods to calculate evapotranspiration. This document presents the results from the implementation of the CEQUEAU model, including evapotranspiration, water levels (in reservoirs, soil and aquifers) and hydrographs. These results show that these new changes provide more hydrology options to the user and with better results.
\end{abstract}

\section{Keywords}

Hydrological Modeling, Flow Simulation, GIS, Cequeau, Idrisi

\section{Introduction}

Surface hydrology has developed considerably as a science primarily because of systematic knowledge of the land phase of the hydrological cycle, its complexity and the difficulty of obtaining exact and detailed meteoro-

How to cite this paper: Diaz Mercado, V., Bâ, K.M., Quentin, E., Ortiz Madrid, F.H. and Gama, L. (2015) Hydrological Model to Simulate Daily Flow in a Basin with the Help of a GIS. Open Journal of Modern Hydrology, 5, 58-67.

http://dx.doi.org/10.4236/ojmh.2015.53006 
logical and hydrometric observations for large areas of drainage basins.

Hydrological models have emerged from the need to calculate the magnitudes of the variables involved in the water cycle. A model is useful to solve a significant number of hydrological studies, such as: reconstitution and generation of long series of data, detection of observation errors, forecasting of extreme events, calculation of flows at ungauged sites, operation of reservoirs and conducting environmental studies, among others. With multidisciplinary approaches, hydrological models are useful to simulate water quality, for example, models that simulate transport of pollutants and those that simulate aquifer levels in agricultural areas, among others [1].

Since the 1970s, the development of computing has stimulated the generation of distributed hydrological models (DHM). Investigations using DHM for large areas are based on the hydrological investigation of processes [2]. Thus, macroscale hydrological models are constructed which can be executed repeatedly over large geographic areas.

DHM have been used to evaluate hydrological conditions (runoff, infiltration, aquifer recharge), the state of vegetation (density, quality) and climate change over large regions. In fact, distributed models can be applied to any type of hydrological problem, including forecasting in basins with no instrumentation.

The use of GIS in hydrological modeling has become more widespread over recent decades. For example, in 1998, the Center for Research in Water Resources (CRWR) at the University of Texas created CRWR-PrePro, a pre-processor in ArcView which extracts information from digital spatial data and makes it available for use by the hydrological program HEC-HMS, which calculates flows [3]-[4].

Molnar and Julien [5] modeled runoff in a basin using the CASCA2D distributed model. Fortin et al. [6]-[7] developed the HYDROTEL distributed model for the purpose of its compatibility with GIS and applied it to the Chaudière River basin (Canada). Chávez and Estrada [8] in the Idrisi Mexico Resources Center (CRI-Méx, Spanish acronym), developed an interface between the CEQUEAU model and ArcView GIS which enables extracting the information required to simulate flows.

It is evident that significant developments have occurred in hydrological models over the past three decades. Three primary factors are involved in these developments: 1) technological advances in geographic information systems (GIS); 2) availability of digital elevation models (DEM) used in GIS; and 3) availability of various digital databases (climatological and hydrometric). This has gradually made it possible to more quickly and accurately obtain the parameters required by hydrological models [9]. The quality of the results depends on the accuracy of the input data and the degree to which the model's structure correctly represents the hydrological process of the problem studied.

\section{Objectives}

The overall objective of this investigation is to implement the CEQUEAU distributed model in the Idrisi geographic information system and apply that model to the study of a hydrological basin to analyze the efficiency and speed of this new tool to simulate flows.

The specific objectives are: implement the CEQUEAU distributed model in a geomatics framework as an additional application of the Idrisi geographic information system; analyze the land use and hydrometeorological information available in a study basin to organize and generate geodatabases; apply the hydrological model implemented in Idrisi to a basin and analyze the results.

\section{Materials and Methods}

\subsection{CEQUEAU Hydrological Model}

This model was developed at the National Institute for Water-Scientific Research (formerly INRS-EAU, now INRS-ETE, French acronyms) at the University of Quebec, Canada to reproduce runoff in a basin [10]. This has been used in different countries for the continuous simulation of flows and for hydrological forecasting for reservoir management [11]-[12]. It is a distributed model in which the basin is divided into square elemental surfaces (parcels) and flows are calculated for each one, taking into account the spatial-temporal variations in the physiographic characteristics. The model consists of two parts to simulate vertical and horizontal water flow in each square (Figure 1). The first part is called the production function and the second is the transfer function.

The production function refers to the modeling of vertical water flow (rainfall, evapotranspiration, infiltration, etc.). This function is aimed at obtaining the water volume for each one of the three recipients included in the model: lakes-marshes, soil and aquifer. The water volume is calculated for each partial element by multiplying 


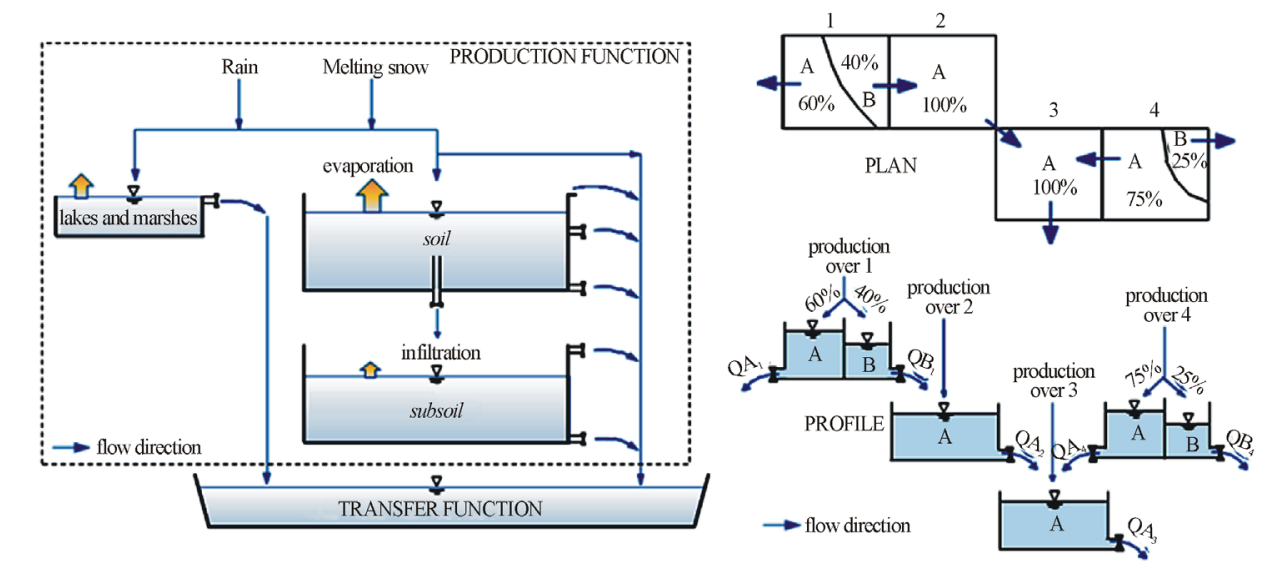

Figure 1. Production function (left) and transfer function (right) for the distributed hydrological model.

the water depth produced in the entire square by the area of the partial element under consideration. The transfer function analyzes the way in which the flow is transferred through the drainage network, taking into account lakes, marshes, dams and bypasses, among other factors. The model examines each parcel for defined time intervals, which can be one day or even one hour.

Evapotranspiration is calculated based on the modified Thornthwaite formula [10]. The calculations are performed according to the time intervals indicated by the user. As shown in the illustration in Figure 1, surface and delayed runoff depend on the water level in the recipients, conceptual draining coefficients and the thresholds of the recipient. This is simulated using equations for the model's parameters which govern the behavior of the water flow in the three recipients (reservoir, soil and aquifer), snow melting, evapotranspiration and channel flow routing.

Two types of input data are required by the model, physiographic and hydrometeorological. The physiographic data are processed for each of the parcels into which the basin is discretized. The use of two-thirds of the hydrometric data is recommended to calibrate the model (estimation of parameters) and the remaining one-third is recommended to validate it.

The model has an application to optimize the model's parameters. The algorithm is based on the Powell method, whose objective function is the Nash coefficient or the correlation coefficient $(r)$. The equations for these calculations are shown by Equations (1) and (2), respectively.

$$
\begin{gathered}
N A S H=1-\frac{\sum_{i=1}^{n}\left(Q c_{i}-Q o_{i}\right)^{2}}{\sum_{i=1}^{n}\left(Q o_{i}-\bar{Q} O\right)^{2}} \\
r=\frac{n \sum_{i=1}^{n}\left(Q o_{i} Q c_{i}\right)-\left(\sum_{i=1}^{n} Q o_{i}\right)\left(\sum_{i=1}^{n} Q c_{i}\right)}{\sqrt{n\left(\sum_{i=1}^{n} Q o_{i}^{2}\right)-\left(\sum_{i=1}^{n} Q o_{i}\right)^{2}}-\sqrt{n\left(\sum_{i=1}^{n} Q c_{i}^{2}\right)-\left(\sum_{i=1}^{n} Q c_{i}\right)^{2}}}
\end{gathered}
$$

where the Nash coefficient is dimensionless; $Q c_{i}$ is the calculated flow on day $i\left(\mathrm{~m}^{3} / \mathrm{s}\right) ; \quad Q o_{i}$ is the observed flow on day $i\left(\mathrm{~m}^{3} / \mathrm{s}\right)$ and; $\bar{Q} 0$ is the average of the observed flows $n\left(\mathrm{~m}^{3} / \mathrm{s}\right)$. The Nash coefficient ranges from $-\infty$ to 1 , where the value 1 corresponds to perfect simulation.

\subsection{Methodology}

To implement the CEQUEAU model in Idrisi, the method proposed by Quentin et al. [13] to develop geomatics modules was followed:

1) The hydrological model was conceptualized for its incorporation in a GIS environment. This primarily involves considering the spatial variability of the information (rain, temperature, land use). 
2) Based on the conceptual model, the geomatic model was developed taking into account the structures and types of operations available in the GIS. Since different geomatics models can be constructed with the same conceptual model, it was necessary to identify the one most useful for the proposed objectives and requirements.

3) The model was implemented as a GIS geomatics model, that is, the algorithm was implemented in programming language.

4) Lastly, the implemented hydrological model was tested with various applications to correct the algorithm and validate the results.

\subsection{Implementation of the CEQUEAU Model in Idrisi}

The hydrological CEQUEAU model was written in Fortran and the applications in Idrisi were implemented in Delphi frameworks base on Pascal language. To this end, the algorithms for the hydrological model needed to be analyzed in order to facilitate the implementation in Delphi.

The number of squares (parcels) into which a basin can be discretized increased, given that the CEQUEAU hydrological model is limited to a maximum of 1000 squares. Nevertheless, since a basin can now be discretized up to the size of the cell (pixel), the dimensions of the square would be defined by the resolution of the matrix file (size of the pixel). Figure 2 illustrates this improvement, where two discretization schemes of a basin are presented, in a) the first scheme the watershed is divided into 235 squares, in b) the second one, into 1,905,015 squares. The Increased in resolution is 100 times more.

The limit of weather stations increased since previously it was only possible to interpolate information for up to 100 stations, which was not convenient when a larger amount existed. Nevertheless, it is now possible to process information from however many stations are available. Also, estimated meteorological data from radar or satellite can now be used.

The transfer function of the CEQUEAU model takes into account the effect of land use (forest, lakes and marshes) in a constant manner, that is, based on only one physiographic file for the entire simulation period. Thus, the forest, lake and marsh areas are assumed to remain unchanged over time. In the CEQUEAU model implemented in Idrisi more than one physiographic file can be used.

The modified Thornthwaite formula [10] is the only method used by the CEQUEAU model to calculate evapotranspiration. Four more criteria were now implemented: Makkink, Turc, Hargreaves-Samani and Penman-Monteith FAO 56. The first three methods mentioned were implemented because they are considered to be more applicable in the different climatic environments in Mexico; the latter was used because it is considered to be the most reliable of the evapotranspiration methods [14].

\subsection{Proposed Geodatabase}

To develop any tool used to perform different applications, the extraction sources for the input information must be defined, since its use is not possible without these data. The present investigation proposes and uses four sources from which input information for the CEQUEAU implemented in the Idrisi GIS can be obtained: CLICOM, BANDAS, USGS and CONABIO.

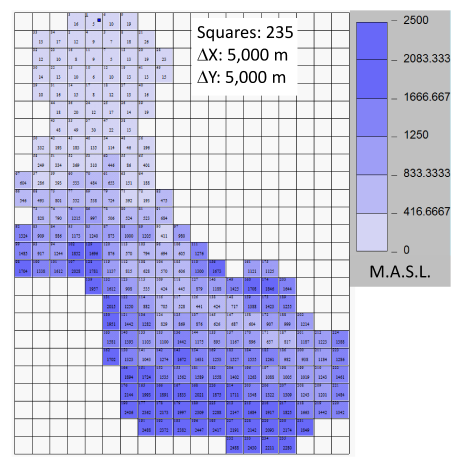

(a)

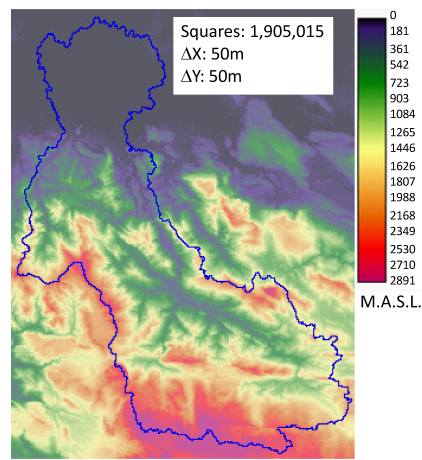

(b)

Figure 2. Discretization schemes: (a) 235 squares (limit 1000) and (b) $1,905,015$ squares. 


\subsubsection{Meteorological \& Hydrometric Data}

Precipitation and maximum and minimum daily temperatures were obtained from the CLICOM database, which can be acquired from the National Weather Service (SMN, Spanish acronym). CLICOM is the database from which the ERIC (Spanish acronym) database is obtained (Rapid Extractor of Climate Information, Extractor Rápido de Información Climatológica) which was also used by this study.

The hydrometric data were taken from the National Surface Water Data Bank (BANDAS, Spanish acronym). This database was obtained from the Mexican Institute for Water Technology (IMTA, Spanish acronym).

\subsubsection{Digital Elevation Model}

The topography of the study area is represented by an image from the Digital Elevation Model (DEM) generated by the US Geological Survey (USGS) based on radar images. The information is raster (matricial) with a resolution of $90 \mathrm{~m} \times 90 \mathrm{~m}$. The DEM image was downloaded from the USGS site (http://earthexplorer.usgs.gov/), introducing the geographic coordinates of the polygon representing the study.

\subsubsection{Land Use}

The land use image for Mexico was obtained from the National Commission for Knowledge and Use of Biodiversity (CONABIO, Spanish acronym) and are vector images at a scale of 1:250,000. The commission developed them by digitalizing topographic maps of the Mexican Republic at that scale. CONABIO developed an interactive download site from which the information can be obtained (http://www.conabio.gob.mx/informacion/gis/).

\subsection{Calibration of the Hydrological Model}

The similarity between the observed and measured $(V o)$ values and those that are simulated $(V c)$ using the hydrological model can be measured or estimated using an objective function or numerical criterion. In general, flow is the variable of greatest interest to calculate using a hydrological model. Nevertheless, depending on the results and the conception of the model, other comparisons can be performed (for example, soil moisture content and evapotranspiration, among others). Table 1 presents four of the objective functions used as evaluation criteria by this work. It also shows the optimal values indicated by a perfect simulation.

\section{Results from the Implementation}

After implementing the CEQUEAU hydrological model in Idrisi, tests were performed to verify its accuracy. These consisted of comparing the results obtained using the developped application with those from the original model for the same set of input data. Figures 3-6 present evapotranspiration, water levels in the soil (HS) \& aquifer $(H N)$ and flow, respectively, calculated with the CEQUEAU model and the model implemented in Idrisi. In all cases, determination coefficients $\left(R^{2}\right)$ and Nash coefficients very close to one were obtained, confirming the correct implementation of the hydrological model.

\section{Application}

The CEQUEAU hydrological model implemented in Idrisi was used to simulate daily flows for the La Sierra River basin (Figure 7), which begins in the central high plains of Chiapas and is $227 \mathrm{~km}$ long with a mean slope

Table 1. Most commonly used objective functions to quantify the modeling error.

\begin{tabular}{|c|c|c|c|c|c|}
\hline & Determination Coefficient & Relative Mean Square Error & Nash Coefficient & Coeffici & ent of Variation Error \\
\hline$R^{2}=$ & $\sum_{i=1}^{n}\left(V o_{i}-\overline{V o}\right)\left(V c_{i}-\bar{V} c\right)$ & ${ }^{1} \Gamma^{n}\left[V o_{i}-V c_{i}\right]^{2}$ & $N A S H=1-\frac{\sum_{i=1}^{n}\left(V c_{i}-V o_{i}\right)^{2}}{2}$ & $\sqrt{\frac{1}{n-1} \sum_{i=1}^{n}}$ & {$\left[\left(V o_{i}-V c_{i}\right)-\frac{1}{n} \sum_{i=1}^{n}\left(V o_{i}-V c_{i}\right)\right]$} \\
\hline & $\sqrt{\left(\sum_{i=1}^{n}\left(V o_{i}-\overline{V O}\right)^{2} \sum_{i=1}^{n}\left(V c_{i}-\bar{V} C\right)^{2}\right.}$ & $\sum_{i=1}\left[\quad V o_{i}\right.$ & $\sum_{i=1}^{n}\left(V o_{i}-\overline{V o}\right)^{2}$ & & $\frac{1}{n} \sum_{i=1}^{n}\left(V o_{i}-V c_{i}\right)$ \\
\hline & Optimal Value: $R^{2}=1$ & $E R C M=0$ & $N A S H=1$ & & $C V E=0$ \\
\hline & Range: $[0,1]$ & {$[0, \infty)$} & $(-\infty, 1]$ & & {$[0, \infty)$} \\
\hline
\end{tabular}

$V o_{i}$ : nth observed value, $V c_{i}$ : nth calculated value, $\overline{V o}$ : Average $n$ values observed, $\overline{V_{c}}$ : Average $n$ values calculated. 


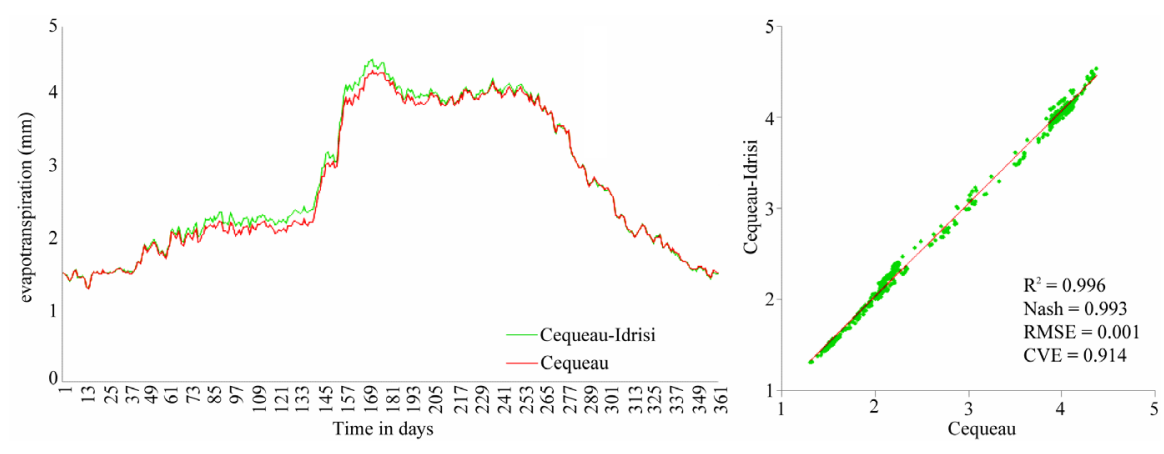

Figure 3. Comparison between inter-annual evapotranspiration ( $\mathrm{mm}$ ) calculated with the CEQUEAU model and the model implemented in Idrisi.
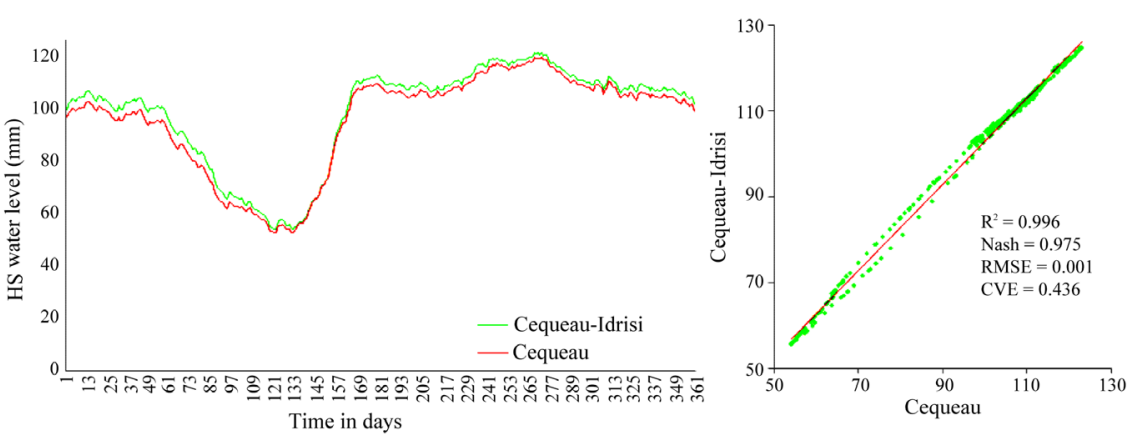

Figure 4. Comparison between inter-annual HS water level (mm) calculated with the CEQUEAU model and the model implemented in Idrisi.
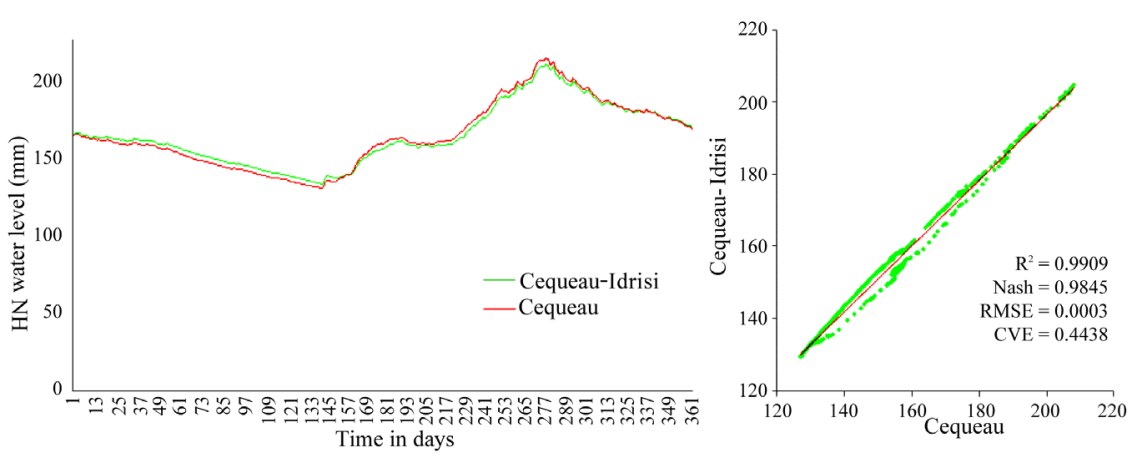

Figure 5. Comparison between inter-annual $H N$ water level $(\mathrm{mm})$ calculated with the CEQUEAU model and the model implemented in Idrisi.
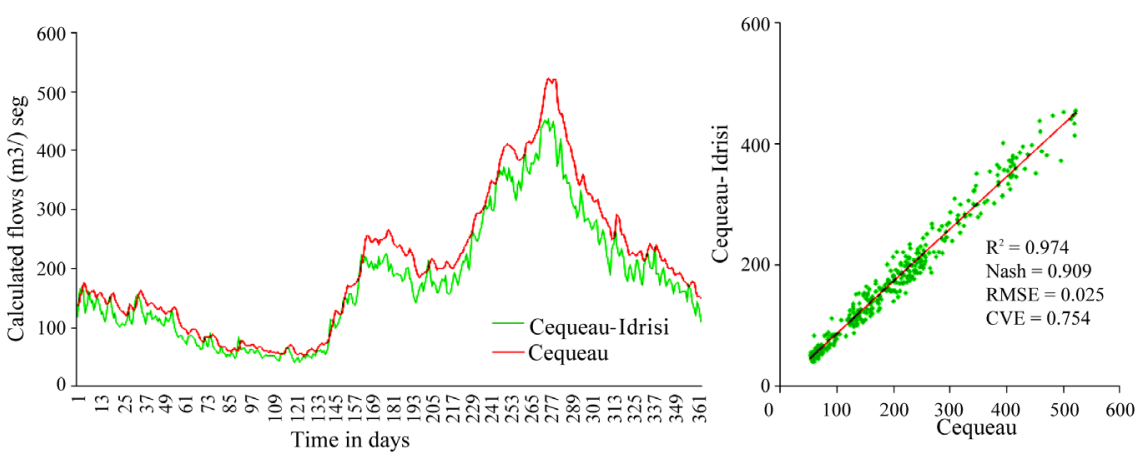

Figure 6. Comparison between inter-annual flows $(\mathrm{mm})$ calculated with the CEQUEAU model and the model implemented in Idrisi. 


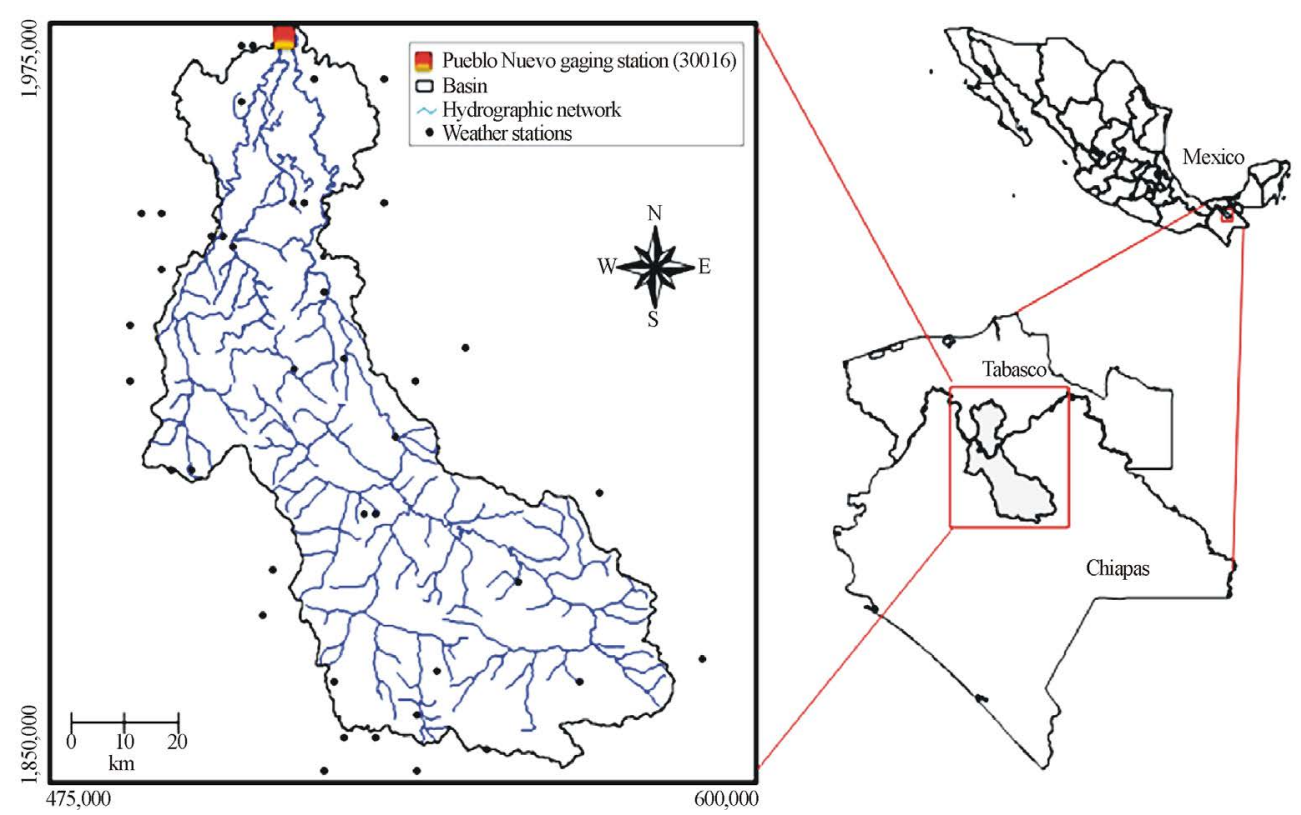

Figure 7. La Sierra River basin Located in Hydrological Region No. 30, Grijalva-Usumacinta, between the States of Chiapas and Tabasco, Mexico.

of $0.96 \%$, anditis located between coordinates $97^{\circ} 40^{\prime} 50^{\prime \prime} \mathrm{N}, 16^{\circ} 40^{\prime} 47^{\prime \prime} \mathrm{W}$ and $92^{\circ} 3^{\prime} 22^{\prime \prime} \mathrm{N}, 17^{\circ} 51^{\prime} 38^{\prime \prime} \mathrm{W}$. This basin is long and exorheic ( 5 order) with high reliefs upstream and flat at the outlet. Its area is $4800 \mathrm{~km}^{2}$ and its perimeter measures $686 \mathrm{~km}$. It is located in hydrological region No.30 Grijalva-Usumacinta where the annual regional precipitation is $4000 \mathrm{~mm}$.

Figure 8(a) shows a compound image from the DEM of the study area for UTM zone 15 with a resolution of $50 \mathrm{~m} \times 50 \mathrm{~m}$. The highest elevations is around 2800 M.A.S.L. Figure 8(b) presents the land use image in matrix format (raster), reclassified according to the land uses included in the CEQUEAU hydrological model: 1) water bodies, 2) forests, 3) marshes and 4) others.

\section{Results from the Application}

The results from the simulation of inter-annual daily flows and monthly mean flows using the Thornthwaite method to calculate reference evapotranspiration for the La Sierra River basin are shown in Figures 9-10, respectively. The result of the simulation was satisfactory since for the case of inter-annual daily flows a Nash coefficient of 0.88 was obtained for the entire period and for monthly mean flows a Nash coefficient of 0.89 was obtained.

The results of the simulation of the inter-annual daily flows and monthly mean flows using the PenmanMonteith FAO 56 method to calculate evapotranspiration are shown in Figures 11-12, respectively. The simulation was satisfactory since for the case of inter-annual daily flows a Nash coefficient of 0.83 was obtained for the entire period and for monthly mean flows a Nash coefficient of 0.84 was obtained.

Although these results are lower than those from the simulation using the Thornthwaite method, the model was calibrated only evapotranspiration method and not for the Penman-Monteith FAO 56. In addition, the latter has been shown to be more applicable than the Thornthwaite method for different climates and latitudes [15] and, therefore, the results will improve with better calibration. The list comparing results between daily recorded and calculated flows is shown in Table 2 for the simulation for 1968 to 1999 (32 years).

\section{Conclusions}

The CEQUEAU hydrological model was implemented in the Idrisi GIS software, taking into account the need to use information from all the weather stations with data available, discretization of the basin into more than 1000 squares if necessary, use of other evapotranspiration methods and the analysis of the effect of the physiographic variability. 

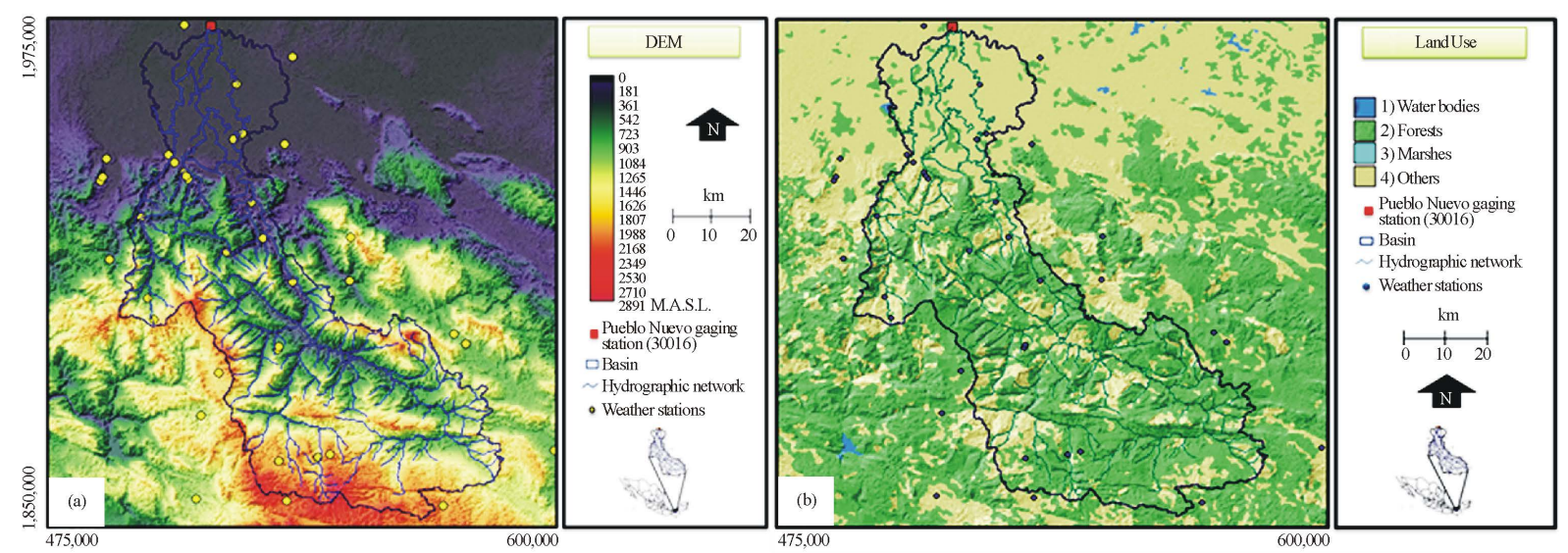

Figure 8. (a) Compound image of the DEM, basin and hydrographic network for the La Sierra River; (b) land use image for the La Sierra River basin.
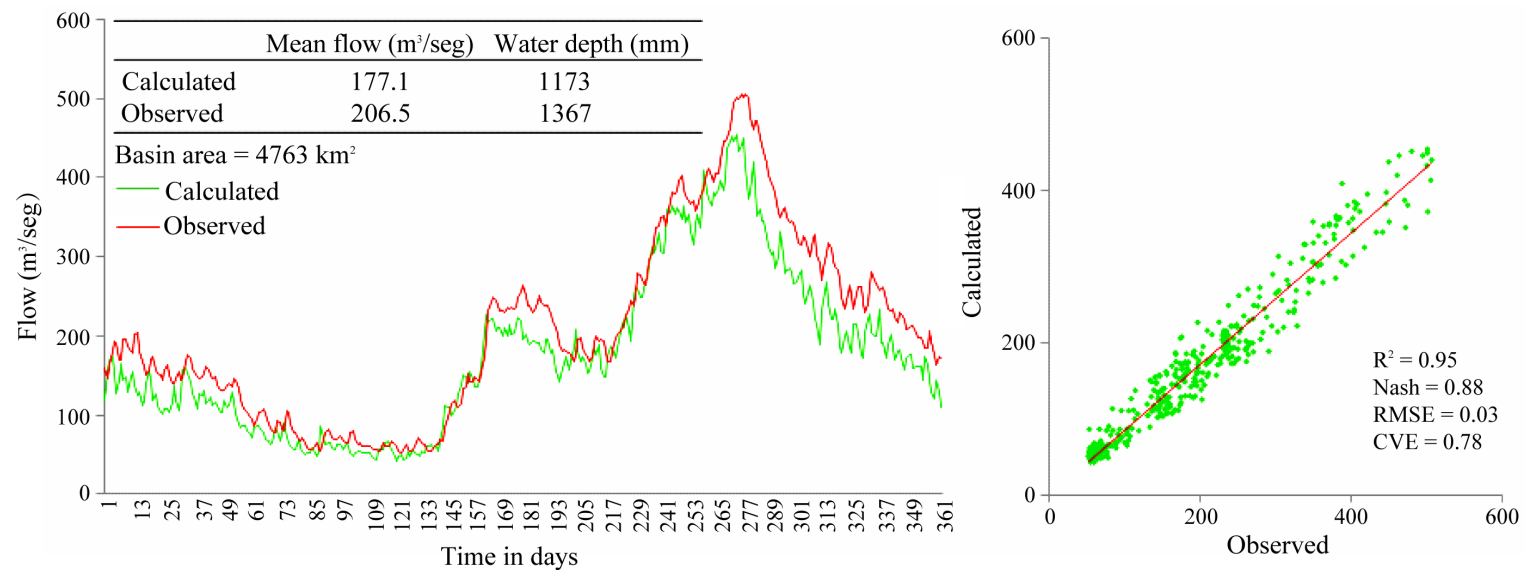

Figure 9. Daily inter-annual calculated and observed flows $\left(\mathrm{m}^{3} / \mathrm{sec}\right)$ at the Pueblo Nuevo station (30016) using the implemented CEQUEAU hydrological model, Thornthwaite method.
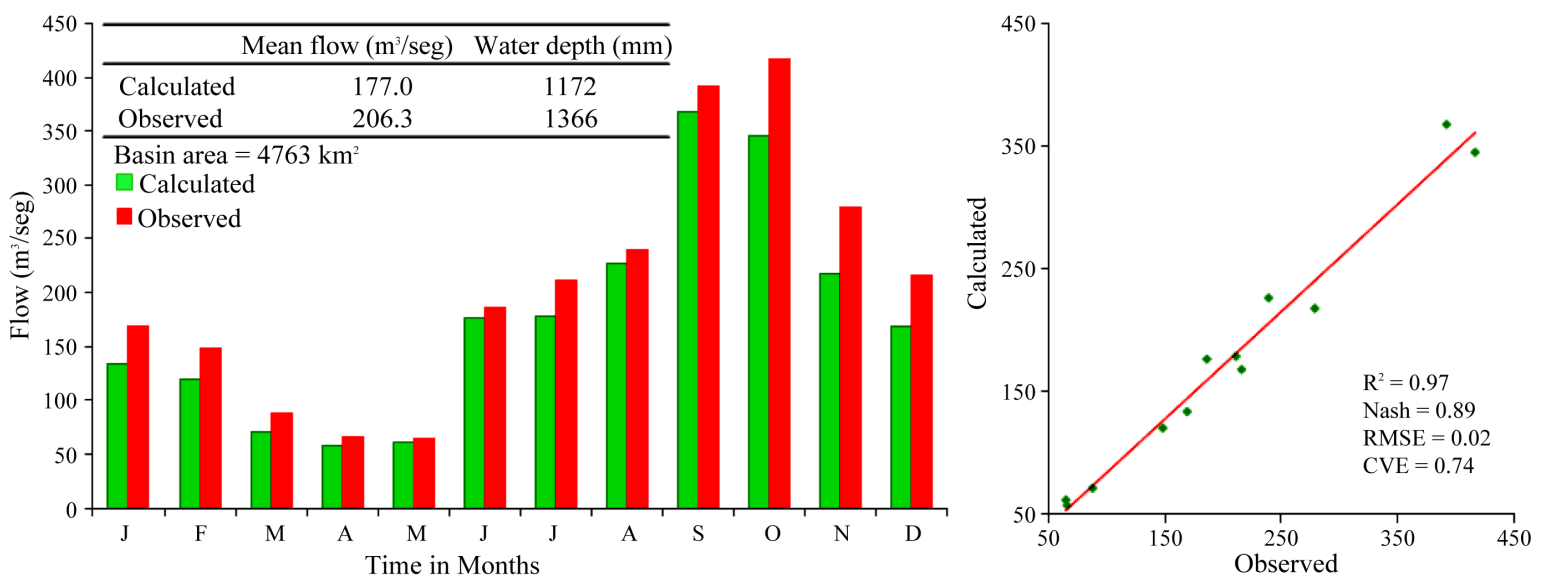

Figure 10. Calculated and observed monthly mean flows $\left(\mathrm{m}^{3} / \mathrm{sec}\right)$ at the Pueblo Nuevo station (30016) using the implemented CEQUEAU hydrological model, Thornthwaite method.

To calculate evapotranspiration, it was possible to implement several calculation methods with a minimal amount of information needed for the analysis, such as maximum and minimum temperatures and the geographic location of the study area. In addition to performing the Thornthwaite method which is used with the CEQUEAU 


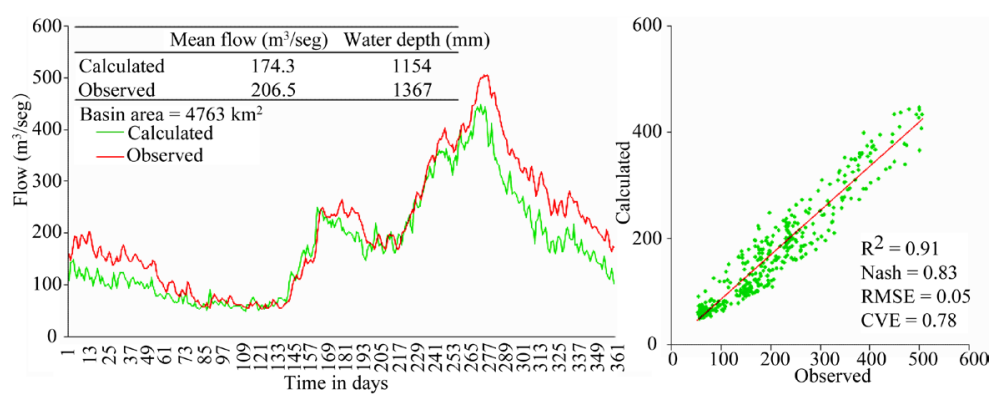

Figure 11. Calculated and observed inter-annual daily flows $\left(\mathrm{m}^{3} / \mathrm{sec}\right)$ at the Pueblo Nuevo station (30016) using the implemented CEQUEAU hydrological model, Penman-Monteith FAO 56.

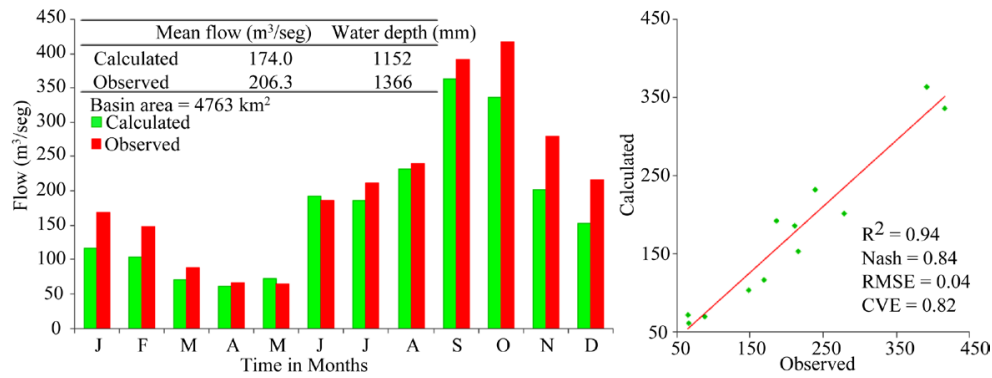

Figure 12. Calculated and observed monthly mean flows $\left(\mathrm{m}^{3} / \mathrm{sec}\right)$ at the Pueblo Nuevo station (30016) using the implemented CEQUEAU hydrological model, Penman-Monteith FAO 56.

Table 2. Numerical criteria to evaluate the simulations of daily flows based on different scenarios.

\begin{tabular}{|c|c|c|c|c|c|c|c|c|}
\hline \multirow{2}{*}{ Year } & \multicolumn{4}{|c|}{ Thornthwaite } & \multicolumn{4}{|c|}{ Penman-Monteith FAO 56} \\
\hline & $\mathrm{R}^{2}$ & Nash & RMSE $^{*}$ & $\mathrm{CVE}^{* *}$ & $\mathrm{R}^{2}$ & Nash & RMSE $^{*}$ & $\mathrm{CVE}^{* *}$ \\
\hline 1968 & 0.88 & 0.84 & 0.04 & 1.26 & 0.81 & 0.76 & 0.07 & 0.88 \\
\hline 1969 & 0.98 & 0.95 & 0.04 & 1.04 & 0.93 & 0.93 & 0.14 & 0.69 \\
\hline 1970 & 0.93 & 0.92 & 0.03 & 1.01 & 0.9 & 0.9 & 0.05 & 0.85 \\
\hline 1971 & 0.91 & 0.9 & 0.03 & 1.05 & 0.91 & 0.91 & 0.03 & 1.03 \\
\hline 1972 & 0.89 & 0.88 & 0.02 & 1.24 & 0.76 & 0.76 & 0.05 & 0.93 \\
\hline 1973 & 0.92 & 0.85 & 0.04 & 1.4 & 0.9 & 0.84 & 0.07 & 1.15 \\
\hline 1974 & 0.95 & 0.9 & 0.03 & 0.9 & 0.93 & 0.9 & 0.05 & 1.1 \\
\hline 1975 & 0.98 & 0.98 & 0.04 & 0.98 & 0.96 & 0.96 & 0.12 & 0.75 \\
\hline 1976 & 0.95 & 0.94 & 0.02 & 0.97 & 0.9 & 0.88 & 0.04 & 0.7 \\
\hline 1977 & 0.94 & 0.91 & 0.03 & 1 & 0.87 & 0.84 & 0.03 & 0.83 \\
\hline 1978 & 0.95 & 0.94 & 0.01 & 0.84 & 0.96 & 0.93 & 0.02 & 0.87 \\
\hline 1979 & 0.97 & 0.86 & 0.05 & 0.79 & 0.93 & 0.84 & 0.09 & 0.8 \\
\hline 1980 & 0.97 & 0.93 & 0.03 & 0.65 & 0.93 & 0.9 & 0.04 & 0.68 \\
\hline 1981 & 0.94 & 0.91 & 0.03 & 0.97 & 0.94 & 0.91 & 0.02 & 1.01 \\
\hline 1982 & 0.94 & 0.91 & 0.04 & 0.66 & 0.97 & 0.91 & 0.03 & 0.92 \\
\hline 1983 & 0.95 & 0.95 & 0.02 & 0.92 & 0.91 & 0.9 & 0.03 & 0.94 \\
\hline 1984 & 0.98 & 0.94 & 0.02 & 0.85 & 0.97 & 0.9 & 0.05 & 0.68 \\
\hline 1985 & 0.82 & 0.71 & 0.06 & 0.65 & 0.73 & 0.5 & 0.09 & 0.54 \\
\hline 1986 & 0.69 & 0.36 & 0.13 & 0.75 & 0.6 & 0.2 & 0.12 & 0.89 \\
\hline 1987 & 0.58 & 0.46 & 0.21 & 0.77 & 0.48 & 0.32 & 0.28 & 0.81 \\
\hline 1988 & 0.95 & 0.95 & 0.04 & 0.84 & 0.93 & 0.91 & 0.07 & 1.02 \\
\hline 1989 & 0.96 & 0.78 & 0.09 & 0.94 & 0.94 & 0.69 & 0.09 & 1.05 \\
\hline 1990 & 0.94 & 0.71 & 0.09 & 0.84 & 0.9 & 0.57 & 0.1 & 0.94 \\
\hline 1991 & 0.86 & 0.63 & 0.08 & 1 & 0.74 & 0.46 & 0.1 & 1.01 \\
\hline 1992 & 0.86 & 0.71 & 0.1 & 0.62 & 0.85 & 0.63 & 0.11 & 0.68 \\
\hline 1993 & 0.84 & 0.7 & 0.08 & 0.81 & 0.82 & 0.6 & 0.11 & 0.8 \\
\hline 1994 & 0.73 & 0.59 & 0.08 & 1 & 0.61 & 0.34 & 0.11 & 1.17 \\
\hline 1995 & 0.91 & 0.81 & 0.06 & 1.04 & 0.9 & 0.7 & 0.1 & 0.96 \\
\hline 1996 & 0.86 & 0.24 & 0.13 & 0.75 & 0.78 & -0.02 & 0.17 & 0.78 \\
\hline 1997 & 0.77 & 0.26 & 0.17 & 0.91 & 0.72 & 0.11 & 0.18 & 0.95 \\
\hline 1998 & 0.71 & 0.69 & 0.47 & 0.94 & 0.53 & 0.51 & 0.68 & 1.02 \\
\hline 1999 & 0.96 & 0.88 & 0.08 & 0.81 & 0.93 & 0.79 & 0.1 & 0.82 \\
\hline
\end{tabular}

"RMSE: relative mean square error; ${ }^{* *} \mathrm{CVE}$ : coefficient of variation error. 
hydrological model, methods that better adapt to Mexico's climatic characteristics were selected: Penman-Monteith FAO 56, Hargreaves-Samani, Turc and Makkink.

The availability of spatially distributed information, hydrometeorological data and the radar-generated Digital Elevation Model (DEM) helped to create the geodatabase required by the study, which enabled developing and applying the CEQUEAU hydrological model implemented in Idrisi.

The main objective was met, which was to implement the CEQUEAU distributed model in Idrisi and apply this model to the study of a hydrological basin under different scenarios. In addition, the efficiency of this new tool to simulate flows was analyzed and satisfactory results were obtained (Nash coefficients of 0.83 to 0.88 for inter-annual daily flows).

\section{Acknowledgements}

The authors thank the National Council on Science and Technology (Consejo Nacional de Ciencia y Tecnología (CONACyT, Spanish acronym)) for the scholarship to graduate studies. In addition, this work was financed by the CONACyT research project 90637 and UEAM projects 3459/2013CH and 2752/2009, the latter provided by the Juarez Autonomous University of Tabasco. The authors would like to thank the anonymous reviewers for their constructive comments, which helped to improve the manuscript.

\section{References}

[1] Ba, K.M., Díaz-Delgado, C. and Rodríguez-Osorio, V. (2001) Simulación de caudales de los ríos Amacuzac y San Jerónimo en el Estado de Mexico, Mexico. Ingeniería Hidráulicaen México (IHM), 16, 117-126.

[2] Venneker, R.G. and Bruijinzeel, L.A. (1997) The IHE-VUA Cathment Research and Modelling lnifiafive (CRMI). The IHE-VUA Catchment Research and Modelling Initiative CRMI-RN-001. IIHHEE, Delfl, Vrije Universiteit Amsterdam, The Netherlands.

[3] Olivera, F., Reed, S. and Maidment, D.R. (1998) HEC-PrePro v. 2.0: An ArcView Pre-Processor for HEC’s Hydrologic Modeling System. 1998 ESRI User's Conference, 25-31 July 1998, San Diego.

[4] Olivera, F. and Maidment, D.R. (1999) GIS Tools for HMS Modeling Support. 1999 ESRI User's Conference, Sandiego.

[5] Molnar, D.K. and Julien, P.Y. (2000) Grid-Size Effects on Surface Runoff Modeling. Journal of Hydrologic Engineering, 5, 8-16. http://dx.doi.org/10.1061/(ASCE)1084-0699(2000)5:1(8)

[6] Fortin, J.P., Turcotte, R., Massicotte, S., Moussa, R., Fitzback, J. and Villeneuve, J.P. (2001) A Distributed Watershed Model Compatible with Remote Sensing and GIS Data. I: Description of Model. Journal of Hydrologic Engineering, 6, 91-99. http://dx.doi.org/10.1061/(ASCE)1084-0699(2001)6:2(91)

[7] Fortin, J.P., Turcotte, R., Massicotte, S., Moussa, R., Fitzback, J. and Villeneuve, J.P. (2001) A Distributed Watershed Model Compatible with Remote Sensing and GIS Data II: Application to Chaudiere Watershed. Journal of Hydrologic Engineering, 6, 100-108. http://dx.doi.org/10.1061/(ASCE)1084-0699(2001)6:2(100)

[8] Chávez, M.I. and Estrada, B. (2005) Programación de una interfaz entre el modelo hidrológico CEQUEAU y el SIG ArcView. Bacherlors Thesis, Universidad Autónoma del Estado de México, Facultad de Ingeniería, Toluca.

[9] He, C. and Croley II, T.E. (2007) Application of a Distributed Large Basin Runoff Model in the Great Lakes Basin. Control Engineering Practice, 15, 1001-1011.http://dx.doi.org/10.1016/j.conengprac.2007.01.011

[10] Morin, G. and Paquet, P. (2007) Modèle Hydrologique CEQUEAU. Rapport de Recherche no R000926, INRS-ETE.

[11] Ayadi, M. and Bargaoui, Z. (1998) Modélisation des écoulements de l’oued Miliane par le modèle CEQUeau. Journal des Sciences Hydrologiques, 43, 741-758.http://dx.doi.org/10.1080/02626669809492170

[12] Eleuch, S., Carsteanu, A.A., Ba, K., Magagi, R., Goita, K. and Díaz-Delgado, C. (2010) Validation and Use of Rainfall Radar Data to Simulate Water Flows in the Río Escondido Basin. Stochastic Environmental Research \& Risk Assessment, 24, 559-565.http://dx.doi.org/10.1007/s00477-009-0336-9

[13] Quentin, E., Díaz-Delgado, C., Gómez-Albores, M.A., Manzano-Solís, L.R. and Franco-Plata, R. (2007) Desarrollo geomático para la gestión integrada del agua. XI Conferencia Iberoamericana de Sistemas de Información Geográfica (XI CONFIBSIG), 21pp.

[14] Campos-Aranda, D.F. (2005) Estimación empírica de la ETP en la República Mexicana. Ingeniería Hidráulica en México (IHM), 20, 99-110.

[15] Allen, R., Pereira, L., Dirk, R. and Smith, M. (2006) Evapotranspiración del cultivo. Guía para la determinación de los requerimientos de agua para los cultivos. FAO. Roma. ftp://ftp.fao.org/agl/aglw/docs/idp56s.pdf 